\title{
Photosynthetic response of Gonyaulax tamarensis during growth in a natural bloom and in batch culture
}

\author{
Patricia M. Glibert ${ }^{1}$, Todd M. Kana ${ }^{1}$, Donald M. Anderson ${ }^{2}$ \\ ${ }^{1}$ Horn Point Environmental Laboratories, University of Maryland, PO Box 775, Cambridge, Maryland 21613, USA \\ ${ }^{2}$ Woods Hole Oceanographic Institution, Woods Hole, Massachusetts 02543, USA
}

\begin{abstract}
The photosynthetic behavior of the dinoflagellate Gonyaulax tamarensis was investigated using single-cell isolation techniques at various stages during growth in a natural bloom in Salt Pond, Massachusetts, USA, and in laboratory cultures. Cell-specific photosynthetic capacity ( $P_{\text {max }}$ cell) increased from 0.25 to $0.32 \mathrm{ng} \mathrm{C}$ cell ${ }^{-1} \mathrm{~h}^{-1}$ during bloom development, then dropped sharply to $0.19 \mathrm{ng}$ $\mathrm{C}$ cell ${ }^{-1} \mathrm{~h}^{-1}$ a few days prior to bloom decline. For $G$. tamarensis cultures grown to nitrogen depletion, both $P_{m a x}$ cell and cell-specific light harvesting efficiency $\left(\alpha_{\text {ceul }}\right)$ decreased several-fold as soon as $\mathrm{NO}_{3}^{-}$in the media fell to zero. Several lines of evidence are presented that suggest that nitrogen limitation played an important role in the decline of the G. tamarensis bloom despite the fact that ambient nitrogenous nutrient concentrations did not become depleted in the pond.
\end{abstract}

\section{INTRODUCTION}

Blooms of dinoflagellates can cause visual discoloration of water (red tides) and, on occasion, episodes of shellfish toxicity or fish mortality when toxic species are present. A variety of biological and environmental factors have been implicated in the initiation, maintenance, and decline of these blooms, but the complexity of the problem and the numerous dinoflagellate species involved have hindered prediction and modelling efforts. Some of the factors that have been identified as being potentially important include hydrodynamic events (Margalef et al. 1979, Cullen et al. 1982), diel vertical migration (Eppley et al. 1968, Cullen \& Horrigan 1981, Anderson \& Stolzenbach 1985), life cycle events (Anderson et al. 1983), temperature, salinity, nutrient and/or trace metal effects (Hartwell 1975 , Prakash 1975, Anderson \& Morel 1979, Watras et al. 1982) and grazing (Fiedler 1982, Huntley 1982, Watras et al. 1985). One of the obvious limitations in determining the cause of either the initiation or decline of a bloom in nature is the difficulty in separating effects on growth of the red-tide dinoflagellate per se from the effects on the phytoplankton assemblage as a whole.

On Cape Cod, Massachusetts, USA, there are a number of small, shallow embayments (or salt ponds) that were subject to large blooms of the toxic dino- flagellate Gonyaulax tamarensis (also known as Protogonyaulax tamarensis and Alexandrium tamarense) during the early 1980s. Some of these blooms were sufficiently large and toxic to close the shellfishery for months at a time. These salt ponds have been extensively studied because they support isolated blooms of G. tamarensis for which advective losses are small enough for cyst and motile cell dynamics to be studied throughout bloom events (Anderson \& Wall 1978, Anderson \& Morel 1979, Anderson et al. 1983, Watras et al. 1985). In these embayments, outbreaks of $G$. tamarensis typically begin when spring warming causes germination of benthic resting cysts. $G$. tamarensis appears to be successful in these ponds because its swimming and migration behavior leads to cell accumulations below the surface layer which is removed on the ebb tides (Anderson \& Stolzenbach 1985, Garcon et al. 1986).

The localized nature of these Cape Cod blooms have made them ideal for predictive modelling efforts. One simple model (Watras et al. 1982) was able to accurately predict the general timing and rate of the bloom development phase in several salt ponds, based only on temperature and salinity regulation of growth. However, the timing and extent of the sudden population decreases as the blooms terminated could not be predicted using these 2 variables only. When grazing by 
zooplankton was included in the model, it was shown that there could be an effect on the occurrence or timing of a bloom but that grazing was not a dominant factor in bloom decline (Watras et al. 1985). The loss of cells due to the induction of sexuality, gamete fusion, and cyst formation and deposition was seen to be the major determinant in bloom termination (Anderson et al. 1983). Since laboratory studies of Gonyaulax tamarensis have demonstrated the link between sexual induction and nutrient limitation (Anderson et al. 1984, Anderson \& Lindquist 1985), we hypothesized that nutrient stress, particularly nitrogen limitation, is an important factor in the decline of blooms in Cape Cod ponds, and that one of the manifestations of limitation would be a change in the photosynthetic competence, and hence vigor, of the cells. Because seasonal changes in the natural light field may also cause changes in the photosynthetic response, we attempted to separate nitrogen and light effects. We conducted our field studies in one Cape Cod salt pond that had exhibited a number of relatively severe blooms and for which much was known about its recent physical and chemical history (Watras et al. 1982, Anderson et al. 1983, Anderson \& Stolzenbach 1985).

\section{METHODS}

Field studies. The study area was Salt Pond, Eastham, Massachusetts, USA. Salt Pond has an average depth (low tide) of ca $3.5 \mathrm{~m}$, and an average salinity of $31 \%$. The pond is connected to the ocean by a narrow inlet channel, which restricts tidal flushing. Other features of the pond are given in Anderson et al. (1983) and Anderson \& Stolzenbach (1985).

Depth-integrated water samples were collected during May and June 1983 between 0700 and 0800 h by lowering a rigid PVC sampling tube to near bottom, closing the tube, and transferring the sample to a carboy. On each sampling day, approximately 6 such samples were collected from different locations around the pond. Temperatures of the depth-integrated samples were recorded. Prior to transporting the sample to the laboratory, a portion was filtered in the field and stored frozen in acid-cleaned high-density polyethylene bottles for nutrient determinations (Strickland \& Parsons 1972).

The carboy was transported to the laboratory in dim light. Approximately 2 h elapsed between collection of the sample and the beginning of experiments. In the laboratory the sample was subdivided for analysis in the following way. Gonyaulax tamarensis cells were concentrated from a $500 \mathrm{ml}$ aliquot by filtering onto a $10 \mathrm{um}$ Nitex net and immediately washing the cells off the filter with $5 \mathrm{ml}$ of $0.2 \mu \mathrm{m}$ filtered seawater From this sample $G$. tamarensis cells were enumerated under $250 \times$ magnification in a Palmer-Maloney counting chamber (Anderson et al. 1983).

The remaining water sample (selected sampling dates only) was split into five $450 \mathrm{ml}$ portions for photosynthesis measurements. The samples were placed in polycarbonate bottles and positioned in a water-cooled incubation tank. A bank of GE $120 \mathrm{~W}$ 'Miser' incandescent floodlights provided a range of intensities, with excess illumination attenuated by one or more layers of fiberglass window screening secured on the outside of the tank. Light scatter between compartments in the tank was prevented by opaque baffles. Photosynthetically available radiation (quantum scalar irradiance) was measured inside each sample bottle with a submersible quantum probe with a $4 \pi$ collector (Biospherical Instruments QSL-100).

The photosynthetic determinations were begun by adding $\mathrm{H}^{14} \mathrm{CO}_{3}^{-}$to each polycarbonate bottle to a final concentration of $0.9 \mathrm{mCi}^{-1}$. During the $5 \mathrm{~h}$ incubation period subsamples of $10 \mathrm{ml}$ were collected at $0.5,1,3$, and $5 \mathrm{~h}$ to determine the amount of radioactivity incorporated by the entire phytoplankton assemblage. After $5 \mathrm{~h}$, the remaining sample was filtered through a $10 \mu \mathrm{m}$ Nitex net, and the cells were washed with $5 \mathrm{ml}$ of filtered seawater. Under a compound microscope, individual cells of Gonyaulax tamarensis were withdrawn with a micropipette (Rivkin \& Seliger 1981), transferred to a clean drop of filtered seawater, then withdrawn again and transferred to a Nalgene filmware bag. The incorporated radioactivity was counted with a Beckman LS-100 scintillation counter, using ScintiVerse II (Fisher Scientific) as the fluor. Each measurement required isolating 20 to 50 cells; in our experiments duplicate or triplicate determinations were made for each experimental treatment. Replicate determinations (cpm per cell) typically varied by $<10 \%$. During the last 2 field experiments, planozygotes (swimming zygotes which form prior to cyst formation) of $G$. tamarensis were isolated by the same technique. These cells could be differentiated from vegetative cells by their large size and dark brown pigmentation (Anderson et al. 1983),

The photosynthetic rates of the entire phytoplankton assemblage were determined by filtration through $25 \mathrm{~mm}$ Whatman GF/F glass fiber fulters under a vacuum differential of $<100 \mathrm{~mm} \mathrm{Hg}$. Filters were rinsed with ca $40 \mathrm{ml}$ of filtered seawater after little $(<1 \mathrm{~s})$ or no intervening air exposure, and fumed over concentrated $\mathrm{HCl}$ for $>45 \mathrm{~s}$. Controls revealed that this treatment removed essentially all residual inorganic ${ }^{14} \mathrm{C}$. Radioactivity on the filters was determined by placing the filters in Nalgene filmware bags with $3 \mathrm{ml}$ of ScintiVerse II, then liquid scintillation counting as above. Specific activities were determined on $0.1 \mathrm{ml}$ of 
the sample in $10 \mathrm{ml}$ of ScintiVerse II and $0.05 \mathrm{ml}$ of phenethylamine.

During this study, surface solar radiation was measured with an Eppley pyrheliometer located on the roof of the Clark Laboratory at the Woods Hole Oceanographic Institution (courtesy of R. Payne), approximately $70 \mathrm{~km}$ from the study site.

Laboratory studies. Gonyaulax tamarensis (clone GTMP: isolated from Mill Pond, Orleans, Massachusetts by D. Anderson in 1977), was grown on a 14L:10D photopheriod using a multi-tube batch technique (Anderson \& Lindquist 1985) which involved growing multiple $25 \mathrm{ml}$ cultures in Pyrex culture tubes $(25 \times 150 \mathrm{~mm})$. During an experiment the contents of an entire tube were sacrificed for a single analysis. This approach has been shown to be necessary for this species because $G$. tamarensis cells are extremely sensitive to the mixing and bubbling that are necessary when growing larger volume cultures. The media for the cultures contained $f / 2$ levels of trace metals, chelators, vitamins, and $\mathrm{PO}_{4}^{3-}$ (Guillard \& Ryther 1963); $\mathrm{NO}_{3}^{-}$levels were either $f / 20$ or $f / 40$, depending on the experiment. This medium has been shown to promote the development of planozygotes and encystment of $G$. tamarensis (Anderson et al. 1984, Anderson \& Lindquist 1985). Cells were harvested for experimentation approximately $5 \mathrm{~h}$ after the beginning of the light period.

In the batch cultures, growth rate was determined by daily monitoring of fluorescence of either selected tubes or of all the tubes, and from cell counts taken from selected tubes. Previous experience has shown that a coefficient of variation of 5 to $10 \%$ is typical for growth rate and cell number among tubes (Watanabe et al. 1982, Anderson \& Lindquist 1985). Concentration of $\mathrm{NO}_{3}^{-}$was also determined from selected tubes on the days on which photosynthesis experiments were conducted (Strickland \& Parsons 1972).

Two types of laboratory experiments were conducted. The first involved the determination of the photosynthesis versus irradiance ( $P$ vs $l$ ) response of nutrient-sufficient Gonyaulax tamarensis adapted to 2 different growth light intensities $(100$ and $280 \mu \mathrm{E}$ $\mathrm{m}^{-2} \mathrm{~s}^{-1}$ ). The second type of experiment involved determination of the $P$ vs $I$ response of $G$. tamarensis at a single light intensity $\left(300 \mu \mathrm{E} \mathrm{m}^{-2} \mathrm{~s}^{-1}\right)$ but at various levels of nitrogen availability in a batch culture. Each $P$ vs $I$ determination was made by first removing a $3 \mathrm{ml}$ subsample from every culture tube, preserving that sample in Lugol's solution for subsequent cell counts, then positioning the tubes with remaining sample in individual compartments in the same acrylic tank described above for the field studies. The tank was illuminated, and irradiance in each tube measured as above. Each tube was incubated with $3 \times 10^{-3} \mu \mathrm{Ci} \mathrm{ml} l^{-1}$
$\mathrm{H}^{14} \mathrm{CO}_{3}$ for $1 \mathrm{~h}$. Experiments were terminated by filtering the contents of an entire tube through Whatman $\mathrm{GF} / \mathrm{F}$ filters. The filters were placed in Nalgene filmware bags, acidified with 2 drops of concentrated $\mathrm{HCl}$, and, after $1 \mathrm{~h}$, the fluor was added. The vials were allowed to stand overnight to insure complete penetration of the filter by the fluor before counting. Radioactive counts and specific activities were done as described above. Dissolved inorganic carbon concentration was assumed to be $24 \mathrm{mg} \mathrm{l}^{-1}$ based on previous measurements of comparable cultures. Uptake of ${ }^{14} \mathrm{C}$ in darkness was subtracted from that in the light.

Parameter calculations. The initial slopes $(\alpha)$ of the $P$ vs $I$ curves were determined by linear regression. The maximum rate of photosynthesis (Pmax) was determined by calculating the average of the rates observed in the saturated portion of the $P$ vs $I$ curve, or by taking the maximum rate measured if saturation of photosynthesis appeared to be incomplete. Both $\alpha$ and Pmax are expressed throughout this paper on a per cell basis and we use a subscript to denote this way of normalization.

\section{RESULTS}

\section{Field studies}

Ambient concentrations of $\mathrm{NH}_{4}^{+}$and $\mathrm{NO}_{3}^{-}$varied several-fold, while the density of Gonyaulax tamarensis increased from undetectable to greater than $10^{5}$ cells $1^{-1}$ (Fig. 1). Ambient temperature of the pond fluctuated

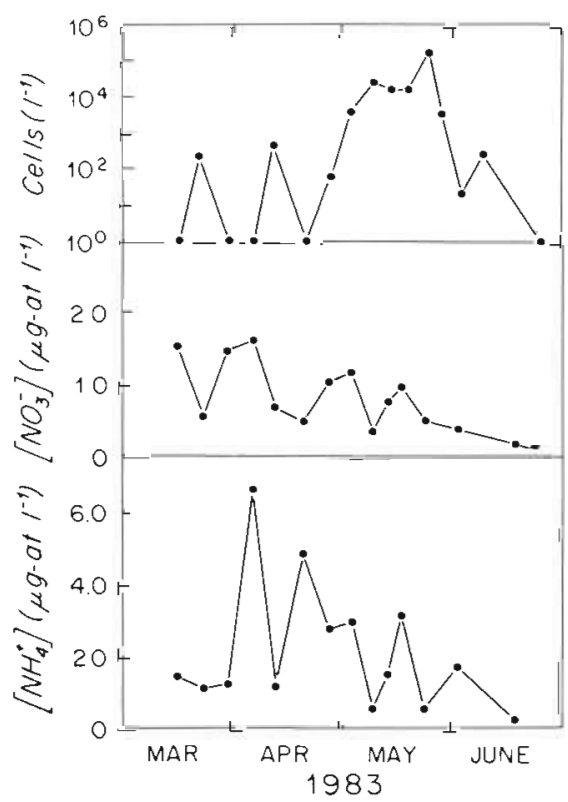

Fig. 1. Concentration of Gonyaulax tamarensis cells and nitrogenous nutrients in Salt Pond, Eastham, Massachusetts, USA, during spring 1983 
between 9 and $14{ }^{\circ} \mathrm{C}$ from mid-May to mid-June. Total daily solar radiation varied greatly from day to day (maximum and minimum values were 7696 and $626 \mathrm{~W}$ $\mathrm{h} \mathrm{m}^{-2}$, respectively); May 1983 was unusually cloudy for this time of year, based on several decades of weather data (R. Payne pers. comm.).

The photosynthetic response of the natural Gonyaulax tamarensis population changed substantially over the course of this sampling period (Fig. 2). During the bloom development phase (early May), the photosynthetic capacity increased by $50 \%$ from initial values. Maximum photosynthetic capacity was observed on the 13 May sampling date. Subsequently, Pmax cell declined by a factor of $\sim 2$ over a $10 \mathrm{~d}$ period (Fig. 2). The reduction in $P \max _{\text {cell }}$ correlated with the appearance of planozygotes but preceded by a few days the decrease in abundance of G. tamarensis (Fig. 1). Planozygotes were photosynthetically active at $\sim 75 \%$ the rate of vegetative cells at all light intensities. Throughout the entire sampling period G. tamarensis contributed $<30 \%$ of the total primary productivity of the pond.

\section{Laboratory studies}

Laboratory studies were designed to explore whether the temporal changes in the $P$ vs $I$ response of Gonyaulax tamarensis in the field might have been due to adaptation to differing irradiance availability or to declining nitrogen nutrient concentrations.

Cultures of Gonyaulax tamarensis pre-adapted to 100 and $280 \mu \mathrm{E} \mathrm{m}^{-2} \mathrm{~s}^{-1}$ growth irradiance yielded values of $\alpha_{\text {cell }}$ and $P$ max $_{\text {cell }}$ that differed by slightly more than a factor of 2 (Fig. 3). The culture grown at the higher light intensity had $\alpha_{\text {cell }}$ and $P$ max $x_{\text {cell }}$ values comparable to those reported from the latter half of the field study; the culture grown at the lower light intensity had values 2 to 2.5 times higher. Yet, for both cultures, when the in situ photosynthetic performances (the photosynthetic rate at the preconditioning growth

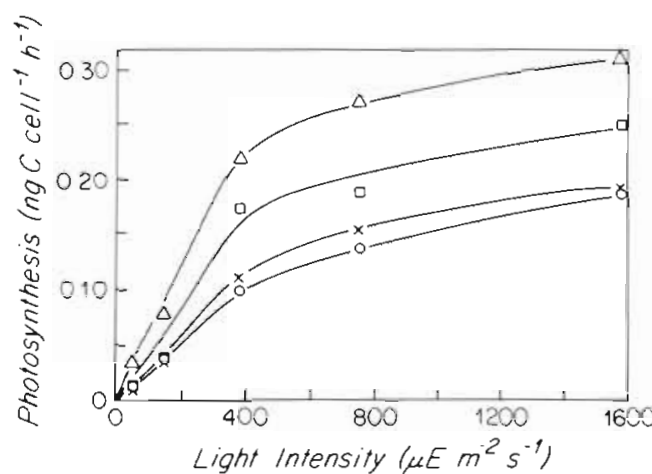

Fig. 2. Gonyaulax tamarensis. Photosynthesis vs irradiance relations at various stages in a natural bloom in Salt Pond,

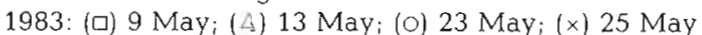

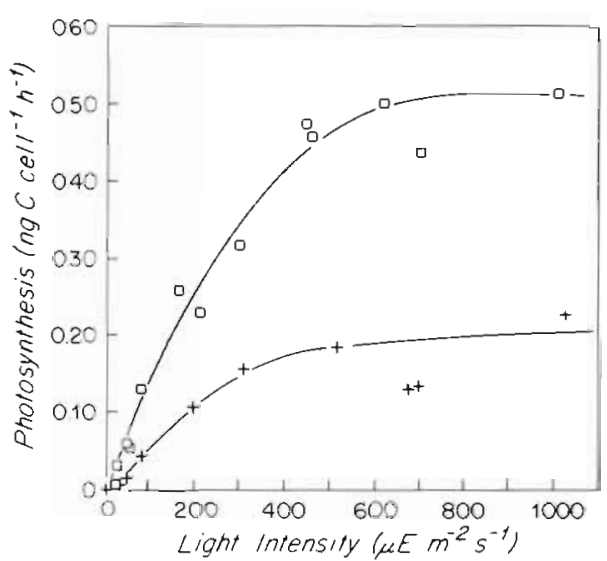

Fig. 3. Gonyaulax tamarensis. Photosynthesis vs irradiance relations of laboratory-grown cultures pre-adapted to different irradiance levels: () $100 \mu \mathrm{E} \mathrm{m}^{-2} \mathrm{~s}^{-1},(+) 280 \mu \mathrm{E} \mathrm{m}^{-2} \mathrm{~s}^{-1}$

irradiance) are compared, the rates are essentially identical at $0.13 \mathrm{ng} \mathrm{C}$ cell ${ }^{-1} \mathrm{~h}^{-1}$.

For cultures that were grown to nitrogen depletion in batch culture, both $\alpha_{\text {cell }}$ and $P m a x_{\text {cell }}$ declined sharply as soon as $\mathrm{NO}_{3}^{-}$in the media dropped to nondetectable levels (Fig. 4). Progressive nitrogen starvation did not result in a substantial further decline of $\alpha_{\text {cell }}$ and Pmax $_{\text {cell }}$.

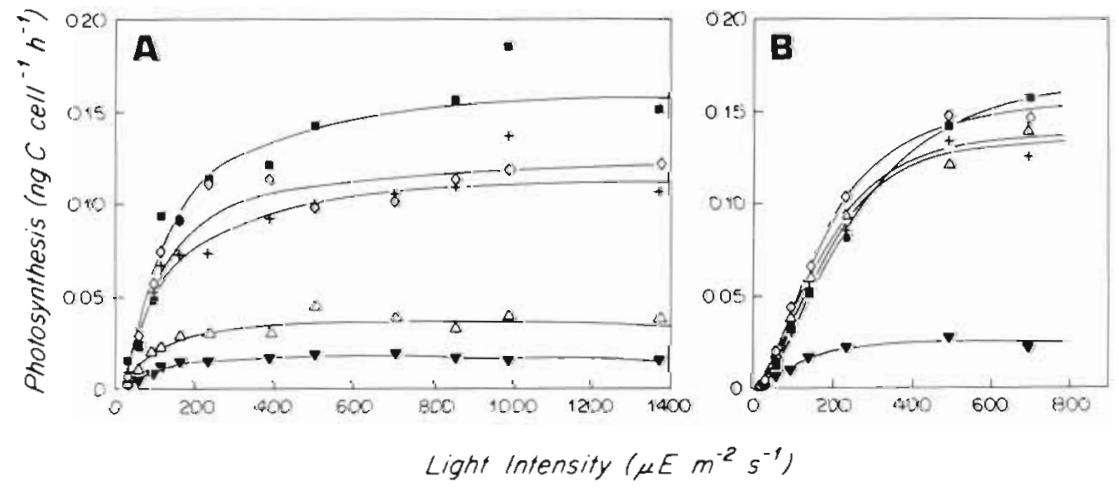

Fig. 4. Gonyaulax tamarensis. Photosynthesis vs irradiance relations of laboratory-grown cultures allowed to become progressively nitrogen depleted. $A$ and $B$ represent separate experiments. $(A)\left(\square_{1} 0\right.$, +) Cultures with $>20 \mu \mathrm{g}$-at I I ${ }^{-1} \mathrm{NO}_{3}^{-}$in the media; $(\Delta, \nabla)$ cultures which were nitrogen depleted for a few hours, and for $5 \mathrm{~d}$ respectively. (B) $\left(\mathbf{m}, \hat{\nu}_{2}+\angle\right)$ Cultures which had $>20 \mu \mathrm{g}$-at $\mathrm{l}^{-1} \mathrm{NO}_{3}^{-}$in the media; $(\mathbf{v})$ culture depleted of nitrogen for $3 \mathrm{~d}$ 


\section{DISCUSSION}

We have shown for one particular outbreak of the red-tide dinoflagellate Gonyaulax tamarensis during May 1983 that the photosynthetic capacity of this species increased when growth of the bloom was in a relatively early phase, but as the bloom aged, both the light harvesting efficiency and photosynthetic capacity declined. Our interest is focussed particularly on the period of decline, as the factors controlling the duration and decline of these red tide outbreaks are little understood. We consider first the impact of naturally fluctuating light availability on the observed photosynthetic parameters.

In order for natural irradiance fluctuations to have had an important controlling role in the photosynthetic performance of Gonyaulax tamarensis in the field, the changes in photosynthetic parameters observed from sampling date to sampling date must be consistent with the change expected from photoadaptation arguments. To support this line of reasoning, any changes in cellular pigment concentration due to photoadaptation would have to be related to the irradiance regime of the previous one to several days (Marra 1980, Prézelin \& Matlick 1980, Perry et al. 1981, Marra \& Heinemann 1982) rather than to the irradiance regime of the sampling day per se, as our sampling time was consistently early morning. The increase in $P$ max $_{\text {cell }}$ and $\alpha_{\text {cell }}$ observed during the early part of the bloom ( 9 to 13 May) would indeed be consistent with 'shade' adaptation (Prézelin 1981, Richardson et al. 1983; Fig. 3): available sunlight prior to 13 May was $<70 \%$ of that prior to 9 May (Table 1). By similar reasoning, the observed decline in $P$ max $x_{\text {cell }}$ and $\alpha_{\text {cell }}$ from 13 to 23 May would be consistent with 'sun' adaptation during the sunnier days 1 to $2 \mathrm{~d}$ prior to 23 May (Table 1). A contradiction of the photoadaptation hypothesis is that the sunlight available prior to the 23 May sampling was less than that prior to the 9 May sampling, yet $\alpha_{\text {cell }}$ and $P_{\text {max cell }}$ were lower on 23 May. Furthermore, maintenance of the lower photosynthetic efficiency and capacity at the end of the bloom (23 to $25 \mathrm{May}$ ) is not consistent with the 2-fold drop in light availability during these $2 \mathrm{~d}$ if photosynthesis were regulated only

Table 1. Average surface solar radiation $\left(\mathrm{W} \mathrm{h} \mathrm{m}^{-2}\right.$ ) for the 1,2 and 3 d preceeding sampling in Salt Pond, May 1983.

(Courtesy R. Payne, Woods Hole Oceanographic Institution)

\begin{tabular}{|lcccc|}
\hline & \multicolumn{4}{c|}{ Sampling date } \\
& 9 May & 13 May & 23 May & 25 May \\
\hline Previous day & 7078 & 4892 & 6521 & 2673 \\
Av. previous 2 d & 7200 & 4500 & 5650 & 3059 \\
Av. previous 3 d & 7338 & 5370 & 4476 & 4213 \\
\hline
\end{tabular}

by the ambient light field of the 1 or $2 \mathrm{~d}$ before sampling. If the $3 \mathrm{~d}$ prior to 23 May and 25 May are examined, there was some consistency in the light field, but such was not the case for the earlier sampling days. These observations suggest that additional factors were important in regulating the photosynthetic response.

Several lines of evidence suggest that nitrogen limitation may have played an important role in the observed decline in $\alpha_{\text {cell }}$ and Pmax cell toward the end of the bloom despite the fact that ambient concentrations of nitrogenous nutrients did not go to zero (Fig. 1). An interactive effect of nutritional status and photoadaptive capability has previously been documented for Gonyaulax polyedra (Prézelin \& Matlick 1983, Prézelin et al. 1986): nitrogen limitation appears to reduce the ability of this species to adapt to bright light and increase its susceptibility to photoinhibition. Prézelin et al. (1986) report that nutrient-limited G. polyedra in early stationary phase of growth show a decrease in $P$ max cell and $\alpha_{\text {cell }}$ of 64 and $60 \%$ respectively when transferred to a higher light regime.

In our study, the evidence for nutrient limitation as an important factor in controlling the Salt Pond bloom is as follows. First, our field observations of reduction in $P$ Pmax $x_{\text {cell }}$ and $\alpha_{\text {cell }}$ during the latter stages of the bloom conform to the same pattern of reduction in these parameters observed in our cultures undergoing progressive nitrogen limitation (Fig. 4). A reduction in photosynthetic parameters during nitrogen limitation and starvation has also been shown for the marine cyanobacterium Synechococcus (Glibert et al. 1986), thus suggesting that cellular regulation of photosynthesis is at least partially coupled to nutrient supply.

Second, by 23 May, when the peak in Gonyaulax tamarensis occurred, more than $30 \%$ of the population was composed of planozygotes (Anderson \& Stolzenbach 1985). It has previously been suggested (Anderson et al. 1984, Anderson \& Lindquist 1985) that as nutrient availability declines, life cycle changes of $G$. tamarensis occur; planozygote formation and subsequent encystment take place only when nutrients become limiting. May 23 was also coincidentally the time when photosynthetic vigor in the field population began dropping. Since the planozygotes isolated from the field were nearly as photosynthetically competent as the vegetative cells, the formation of planozygotes themselves was not controlling the measured photosynthetic behavior of the Gonyaulax population in the field. Rather, reduction in nutrient availability appeared to trigger the change in life cycle, and simultaneously caused a reduction in photosynthetic capacity and efficiency. Reduction in photosynthetic competence of the vegetative cells may thus be an indicator that gametogenesis may soon occur. 
Further supporting the nutrient depletion hypothesis is the fact that during the period of 25 to 26 May Gonyaulax tamarensis tended to aggregate at a lower depth in the water column than has been observed at other times when nutrients were replete and sexual stages not present (Anderson \& Stolzenbach 1985). This behavior has been shown to be typical of several dinoflagellate species under nitrogen limitation (Heaney \& Eppley 1981).

Finally, although direct studies of nitrogen uptake capacity by Gonyaulax have been few, Maclsaac et al. (1979) showed that $G$. excavata has a fairly low affinity for $\mathrm{NO}_{3}^{-}$and $\mathrm{NH}_{4}^{+}$, as inferred from measured halfsaturation $\left(K_{s}\right)$ values. Their reported $K_{s}$ values fall in the range of 1.5 to $2.8 \mu \mathrm{g}$-at $\mathrm{N}^{-1}$, which are, in fact higher than the measured concentrations of $\mathrm{NO}_{3}^{-}$and $\mathrm{NH}_{4}^{+}$from the field when the $P$ vs $I$ parameters began dropping. Accurate definition of the kinetic constant $K_{s}$ has been shown in recent years to be extremely difficult, and questions have been raised regarding the time-dependency of nutrient saturation kinetics (Wheeler et al. 1982, Goldman \& Glibert 1983). In spite of these reservations, the large values of $K_{s}$ reported by Macisaac et al. (1979) would suggest that during the latter half of the May 1983 bloom ambient concentrations of $\mathrm{NO}_{3}^{-}$and $\mathrm{NH}_{4}^{+}$were insufficient to support the maximal uptake capacity of the population.

Thus, while the results of these studies provide only circumstantial evidence that nitrogen limitation played an important role in the photosynthetic competence of Gonyaulax tamarensis undergoing a natural bloom, it is clear that regulation of photosynthesis in the field involved more than photoadaptation to prevailing irradiance levels. More work is now needed to fully understand the role of nutrient availability in photosynthetic regulation, and whether photosynthetic competence can be used diagnostically in predicting the potential duration of a natural bloom.

Acknowledgements. Our appreciation is extended to Dave Kulis for assistance in all aspects of the field and laboratory studies. This project was supported by NOAA Office of Sea Grant NA.84-D-00033 (R/B 59) to P.M.G. and NA84-D-00033 (R/B 56) and NA86-D-SG090 (R/B 76) to D.M.A. This is Contribution No. 1863 from the Center for Environmental and Estuarine Studies, University of Maryland, and No. 6586 from the Woods Hole Oceanographic Institution.

\section{LITERATURE CITED}

Anderson, D. M., Chisholm, S. W., Watras, C. J. (1983). The importance of life cycle events in the population dynamics of G. tamarensis. Mar. Biol. 76: 179-190

Anderson, D. M., Kulis, D. M. Binder, B. J. (1984). Sexuality and cyst formation in the dinoflagellate Gonyaulax tamarensis: cyst yield in batch cultures. J. Phycol. 20 $418-425$
Anderson, D. M., Lindquist, N. L. (1985). Time-course measurements of phosphorus depletion and cyst formation in the dinoflagellate Gonyaulax tamarensis Lebour. J. exp. mar. Biol. Ecol. 85: 1-13

Anderson, D. M., Morel, F. M. M. (1979). The seeding of two red tide blooms by the germination of benthic Gonyaulax tamarensis hypnocysts. Estuar. coast. mar. Sci. 8: 279-293

Anderson, D. M., Stolzenbach, K. D. (1985). Selective retention of two dinoflagellates in a well-mixed estuarine embayment: the importance of diel vertical migration and surface avoidance. Mar. Ecol. Prog. Ser. 25: 39-50

Anderson, D. M., Wall, D. (1978). The potential importance of benthic cysts of Gonyaulax tamarensis and Gonyaulax excavata in initiating toxic dinoflagellate blooms. J. Phycol. 14: 224-234

Cullen, J. J., Horrigan, S. G. (1981). Effects of nitrate on the diurnal vertical migration, carbon to nitrogen ratio, and photosynthetic capacity of the dinoflagellate Gymnodimium splendens. Mar. Biol. 62: 81-89

Cullen, J. J., Horrigan, S. G., Huntley, M. E., Reid, F. M. H. (1982). Yellow water in La Jolla Bay, California, July 1980. I. A bloom of the dinoflagellate Gymnodimium flavum Kofoid \& Swezy. J. exp. mar. Biol. Ecol. 63: 67-80

Eppley, R. W., Holm-Hansen, O., Strickland, J. D. H. (1968). Some observations on the vertical migration of dinoflagellates. J. Phycol. 4: 333-340

Fiedler, P. (1982). Zooplankton avoidance and reduced grazing responses to Gymnodinium splendens (Dinophyceae). Limnol. Oceanogr. 27: 961-965

Garcon, V C., Stolzenbach, K. D., Anderson, D. M. (1986). Tidal flushing of an estuarine embayment subject to recurrent dinoflagellate blooms. Estuaries 9: 179-187

Glibert, P. M., Kana, T. M., Olson, R. J., Kirchman, D. L., Alberte, R. S. (1986). Clonal comparisons of growth and photosynthetic responses to nitrogen availability in marine Synechococcus spp. J. exp. mar. Biol. Ecol. 101: 199-208

Goldman, J. C., Glibert, P. M. (1983). Kinetics of inorganic nitrogen uptake by phytoplankton. In: Carpenter, E. J., Capone, D. G. (eds.) Nitrogen in the marine environment. Academic Press, New York, p. 233-274

Guillard, R. R. L., Ryther, J. H. (1962). Studies of marine planktonic diatoms. I. Cyclotella nana Hustedt and Detonula confervacea (Cleve.) Gran. Can. J. Microbiol. 8: 229-239

Hartwell, A. D. (1975). Hydrodynamic factors affecting the distribution and movement of toxic dinoflagellates in the western Gulf of Maine. In: LoCicero, V. R. (ed.) Toxic dinoflagellate blooms. Proc. 1st Int. Conf. Mass. Sci. and Techn. Foundation, Wakefield, MA.

Heaney, S. I., Eppley, R. W (1981). Light, temperature and nitrogen as interacting factors affecting diel vertical migrations of dinoflagellates in culture. J. Plankton Res. 3: 331-344

Huntley, M. E. (1982). Yellow water in La Jolla Bay, California, July 1980 . II. Suppression of zooplankton grazing. J. exp. mar Biol. Ecol. 63: 81-91

MacIsaac, J. J., Grunseich, G. S., Glover, H. E., Yentsch, C. M. (1979). Light and nutrient limitation in Gonyaulax excavata: nitrogen and carbon trace results. In: Taylor, $D$. L., Seliger, H. H. (eds.) Toxic dinoflagellate blooms. Proc. 2nd Int. Conf. Elsevier/North Holland. New York, p. $107-111$

Margalef, R., Estrada, M., Blasco, D. (1979). Functional morphology of organisms involved in red tides, as adapted to decaying turbulence. In: Taylor, D. L., Seliger, H. H. (eds.) Toxic dinoflagellate blooms. Proc. 2nd Int. Conf Elsevier/ North Holland, New York, p. 89-94 
Marra, J. (1980). Time-course of light intensity adaptation in a marine diatom. Mar. Biol. Lett. 1: 175-183

Marra, J., Helnemann, K. (1982). Photosnythesis response by phytoplankton to sunlight variability. Limnol. Oceanogr 27: 1141-1153

Perry, M. J., Talbot, M. C., Alberte, R. S. (1981). Photoadaptation in marine phytoplankton: response of the photosynthetic unit. Mar. Biol. 62: 91-101

Prakash, A. (1975). Growth and toxicity of a marine dinoflagellate, Gonyaulax tamarensis. J. Fish. Res. Bd Can. 24 1589-1606

Prézelin, B. B. (1981). Light reactions in photosynthesis. In: Platt, T (ed.) Physiological bases of phytoplankton ecology. Can. Bull. Fish. Aquat. Sci. 210: 1-43

Prézelin, B. B., Matlick, H. A. (1980). Time-course of photoadaptation in the photosynthesis-irradiance relationship of a dinoflagellate exhibiting photosynthetic periodicity. Mar. Biol. 58: 85-96

Prézelin, B. B., Matlick, H. A. (1983). Nutrient-dependent lowlight adaptation in the dinoflagellate Gonyaulax polyedra. Mar. Biol. 74: 141-150

Prézelin, B. B., Samuelsson, G., Matlick, H. A. (1986). Photosystem II photoinhibition and altered kinetics of photosynthesis during nutrient-dependent high-light photoadaptation in Gonyaulax polyedra. Mar. Biol. 93: $1-12$
Richardson, K., Beardall, J., Raven, J. A. (1983). Adaptation of unicellular algae to irradiance: an analysis of strategies. New Phytol. 93: 157-191

Rivkin, R. B., Seliger, H. H. (1981). Liquid scintillation counting for ${ }^{14} \mathrm{C}$ uptake of single algal cells isolated from natural samples. Limnol. Oceanogr 26:780-785

Strickland, J. D. H., Parsons, T R. (1972), A practical handbook of seawater analysis. Bull. Fish. Res. Bd Can. 167: $1-310$

Watanabe, M. M., Watanabe, M., Fukuyo, Y (1982). Encystment and excystment of red tide dinoflagellates. I. Induction of encystment of Scrippsiella trochoidea. Eutrophication and red tides in the coastal marine environment. Nat. (Japan) Inst. Envir. Stud. Res. Rep. 30: 27-42

Watras, C. J., Chisholm, S. W., Anderson, D. M. (1982). Regulation of growth in an estuarine clone of Gonyaulax tamarensis: Salinity-dependent temperature responses. J. exp. mar. Biol. Ecol. 62: 25-37

Watras, C. J., Garcon, V. C., Olson, R. J., Chisholm, S. W., Anderson, D. M. (1985). The effect of zooplankton grazing on estuarine blooms of the toxic dinoflagellate Gonyaulax tamarensis. J. Plankton Res. 7: 891-908

Wheeler, P. A., Glibert, P. M., McCarthy, J. J. (1982). Ammonium uptake and incorporation by Chesapeake Bay phytoplankton: short term uptake kinetics. Limnol. Oceanogr. 27: 1113-1128 